ARTICLE

\title{
Eggstraordinary artefacts: decorated ostrich eggs in the ancient Mediterranean world
}

Tamar Hodos (10 ${ }^{1 凶}$

Decorated ostrich eggs were luxury items in antiquity. They were engraved, painted, and embellished with ivory, precious metals and faience fittings. They have been found primarily in elite funerary contexts from Mesopotamia and the Levant to the wider Mediterranean throughout the region's Bronze and Iron Ages (third-first millennia BCE). Most scholarship has assessed their iconography to determine craftsman origin, equating decorative style with cultural identity. This is tenuous at best, given how readily motifs can be copied or adapted, and especially challenging for periods in which artisans were reliant on royal/elite patronage and known to migrate between regions, as during these eras. Furthermore, the full extent of the roles of non-elites in the production and distribution of these elite artefacts has never been considered directly. Thus, the role these luxuries played as social actors across a spectrum of society has been overlooked. It is this aspect that the present work addresses. It does so by building upon a recently concluded study that has used isotopic analyses and scanning electron microscopy to assess where and how eggs were acquired in the ancient Mediterranean and the working techniques used to decorate them. The results allow us to consider the role these objects played as social actors upon more than just their elite consumers. This suggests that, as scholars, we must adopt different questions, methodologies, and thus perspectives, to recognise the wider social effects of luxury material culture and its impact upon diverse groups and individuals beyond wealthy consumers.

\footnotetext{
${ }^{1}$ University of Bristol, Bristol, UK. ${ }^{凶}$ email: t.hodos@bristol.ac.uk
} 


\section{Introduction}

ecorated ostrich eggs were luxury items in the ancient Mediterranean world. They were engraved, painted, and embellished with ivory, precious metals and faience fittings. They have been found primarily in elite funerary contexts from Mesopotamia and the Levant to the wider Mediterranean throughout the region's Bronze and Iron Ages (third-first millennia BCE). Along with decorative objects of ivory, bronze, silver, and gold, they represent shared status indicators of elites across competing, connected cultures of their respective ages (Aruz et al. 2008, 2014). Despite the chrono-cultural differences, they are regarded primarily as evidence of connectivity between communities in the respective networks of the Bronze and Iron Ages; their role as social actors is hardly considered beyond comparative elite display. Yet without consideration of others who may have been involved in their biography prior to deposition, we are left with a limited understanding of the full extent to which the eggs may have served as social actors in antiquity.

To address this, therefore, one must begin with the origin of the eggs. Until recently, their origin has been considered on the basis of their decorative styles. This approach by its nature uses style as proxy for cultural identity of the artisan. It is particularly challenging to use for periods in which artisans were known to be mobile, however, which is the case for the Bronze and Iron Age Mediterranean worlds. A recently concluded study of ancient Mediterranean ostrich eggshell has taken a different approach to determine the eggs' origins (Hodos et al. 2020). As a result, we now have new evidence at hand to enable us to begin to consider the extent to which the decorated ostrich eggs acted upon members of society beyond their final elite consumers.

\section{Eggsemplifying the problem}

Since ostriches are not indigenous to Europe, decorated eggs from Bronze and Iron Age archaeological contexts in regions such as Greece, Italy and Spain must have been imported from the Middle East and/or North Africa, where ostriches were indigenous during these periods (Brysbaert 2013). Production sites are infrequently identified, however, and ostrich bones are rarely found in archaeological contexts. Therefore, assessment of where they came from and who decorated them has relied upon iconographic analysis and comparison with other worked media. This is tenuous at best, given how readily motifs can be copied or adapted (Conkey and Hastorf 1993), and it is especially challenging for periods in which artisans were reliant on royal/elite patronage and known to migrate between regions, as during these eras of Mediterranean history (Gunter 2009, pp. 4-14; Feldman 2014, pp. 11-41). As a result, this has led to differing interpretations about where the producers of such objects might have worked and who might have traded the eggs. There has also been discussion about whether the eggs were blown before shipping (Phillips 2000, p. 333; Brysbaert 2013, p. 250), and how they might have been worked (Evely 1993; Koehl 2006; Kandel 2004, p. 383; Poplin 1995; Brysbaert 2013, pp. 251-252), without any agreed conclusions. Such discussions have also not been able to point with any certainty to where the eggs originated (e.g. Bass 1997, p. 165).

This situation is exemplified by five whole examples in the British Museum (Figs. 1 and 2). They were found in the Isis Tomb, an elite burial at Etruscan Vulci (Italy) dated to between the late seventh and first half of the sixth century BCE (ca. 625-550 BCE). Four were carved and painted; one was just painted. Motifs include animals, flora, geometric patterns, soldiers and chariots. All were fashioned into vessels with metal attachments, although none of the metallic fittings themselves survive.

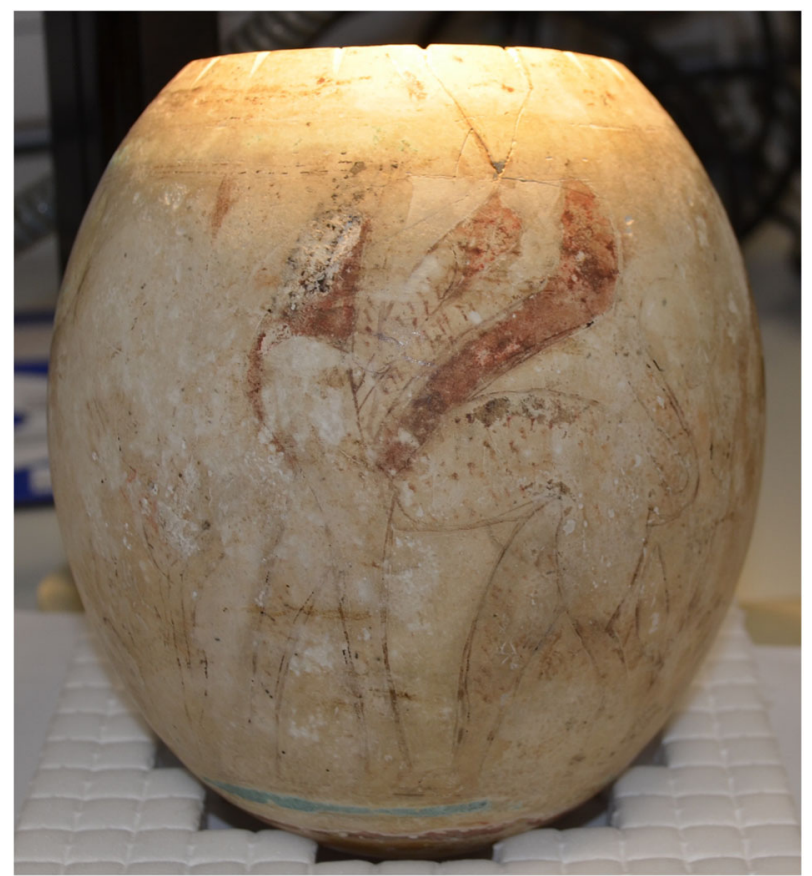

Fig. 1 Painted decoration on an ostrich egg from Vulci, Italy. (c) T. Hodos and reproduced with permission of the Trustees of the British Museum.

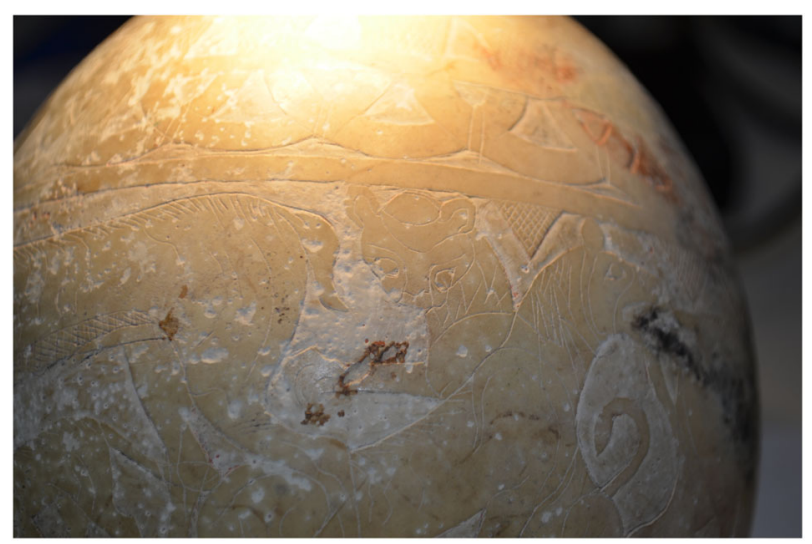

Fig. 2 Incised decoration on an ostrich egg from Vulci, Italy. (c) T. Hodos and reproduced with permission of the Trustees of the British Museum.

The tomb itself was discovered in 1839 on the estate of Napoleon Bonapart's brother, Lucien Bonaparte, Prince of Canino, who had been granted this land to the north-west of Rome by the Pope. The tomb is known as the Isis Tomb because of a bronze statue found in the tomb that was originally thought to be of Isis (but is now regarded as a local work of an Etruscan deity), and other Egyptian paraphernalia, including several faience flasks, seven scarabs, and 33,000 faience beads that have been identified as Egyptian in origin; they were likely strung together as a shroud (Middleton 2009). A gold diadem, a number of bronze utensils and vessels, bucchero pottery, two gold foilcovered terracotta statuettes, and a half life-size gypsum statuette form the rest of the assemblage (Haynes 2000, pp. 154-158).

Whether this assemblage represents the contents of the grave is uncertain, however, for no formal catalogue was made at the time of excavation, and the objects were displayed by Lucien Bonaparte for many years at his villa near Vulci in a cabinet of Egyptian antiquities, which may have included material acquired directly from Egypt (Haynes 1977). Nevertheless, the fusing of a 
number of the Egyptian faience beads to bronzework of Etruscan manufacture does suggest that at least some of what came to the British Museum as a tomb group was likely recovered from an Italian context (Middleton 2009, p. 70; see also Rathje 1986).

Given the mix of objects from Etruria and Egypt, the origin of the ostrich eggs has been the subject of much discussion, which until very recently has been based upon their iconographic style. The motifs and working methods of these eggs have been compared with contemporary Levantine and Mesopotamian ivory working (Barnett 1982; Feldman 2014, pp. 13-18; Hermann 2000; Winter 1976a, 1976b, 1982), whereas skilled ostrich egg decorating during the seventh and sixth centuries BCE is associated with both North Africa and the Levant (e.g. Rathje 1986, p. 400; Savio 2004; Le Meaux 2013). Thus, scholars have debated whether these objects were decorated imports (Torelli 1965; Rathje 1986, p. 400), worked by migrant Phoenician craftsmen in Etruria (Markoe 1992, pp. 78-80), or made by local Etruscan craftsmen who were familiar with eastern Mediterranean styles and techniques (Rathje 1986; Haynes 2000, p. 158; Napolitano 2007).

The geographic origins of the eggs themselves prior to working remain obscure. Yet this is central to the question of who 'made' a decorated egg, for acquisition of the material itself is the first step of the entire chaine opératoire. Since ostriches are not indigenous to Italy, the eggs represent imported objects in one capacity or another (i.e. as finished products or for the raw egg-shell-asmaterial). Furthermore, the Levantine features of their iconography-regardless of whether they were decorated by Phoenicians or other Levantine artisans-distinguishes them from the rest of the Isis Tomb assemblage, which otherwise consists of Italic and Egyptian artefacts. Therefore, their geographic origins are fundamental to the question of who decorated them.

The stylistic approach has brought us no closer to determining their origin, however, because we know that craftsmen were mobile during this period, and we are not always adept at classifying artefacts succinctly when their anonymous (to us) makers moved around and worked for foreign commission. For example, if a Phoenician craftsman was working in the employ of an Assyrian king in Assyria, should we consider the finished product as 'Phoenician' or 'Assyrian'? Even before we can ask this question, there are extensive challenges in defining Levantine styles in the first place, drawn from other worked media, which have rendered it extremely difficult to distinguish what a Phoenician style, especially, might even be (e.g. Winter 1976a; 1976b, 1982; Gunter 2009; Onnis 2013; Feldman 2014). We therefore need a different approach that does not involve a direct stylistic interpretation. This takes us to the chaine opératoire itself of these eggs, which has previously not been considered as a means of understanding their origins.

Understanding their production process also encourages us to consider the full extent to which the eggs might have been social actors. Object materiality is recognised as a major factor in our lived experiences and is a primary means of supporting our interpretations of the past (e.g. Gosden 2005; Ingold 2007; Hicks 2010). The social roles of luxury goods are more frequently considered with regard to status display, both between competing cultures and within a particular culture, but this is only one means by which we might consider objects as social actors. These eggs impacted upon a range of individuals and groups beyond their elite consumers. A new study of ancient Mediterranean ostrich eggshell objects and fragments that explores their full production process (Hodos et al. 2020) not only enables us to examine their origins in an entirely new way from how they have been previously considered, but it also provides a means to consider their role as social actors. First, however, it is necessary to explain what is meant by a luxury object, and ways in which such objects serve as social actors.

\section{Eggstraordinary objects, agency and actors}

An object may be extraordinary for a number of reasons. In the case of these decorated eggs, they are extraordinary for both their exquisite workmanship, material uniqueness, and restricted circulation amongst those of elevated social status. Together, these traits allow us to deem them luxury artefacts. According to the Oxford English Dictionary, a luxury may be designated as such by a combination of several criteria, including that it is extravagant; inessential but highly desirable; and/or difficult to obtain, for reasons of e.g. rarity, expense, and/or risk of acquisition, amongst others. Desirability, comfort, extravagance, or rare pleasure on its own is insufficient for an object to be deemed a luxury (for more, see Hodos 2018).

Perhaps more than this combination is the fact that any notion of a luxury item is predicated upon our understandings of the values such an item imparts to its consumers. This may be in terms of its economic worth, the production chain involved in its manufacture and delivery, and/or the messages we wish to convey to others who might see it in our possession. Not all of these necessarily translate between cultures, though. In other words, our sense of what constitutes a luxury item is not universal. Instead, our understanding of what luxury might be is culturally specific, although often we find such understandings are culturally shared. For example, many cultures around the world today recognise western designer clothes, private airplanes, supercars, gold, and gemstones as luxury items.

This is not to say that if an object is not a luxury, then it must be a necessity. An object's designation as such depends upon several factors, particularly its context within a given society, and our social awareness of relative value within that society. For example, wine may be a necessity in certain religious contexts, although it often is regarded as a luxury in social ones. A car, which may be deemed an extravagance, can also be the only practical means of transportation depending upon where an individual lives, which renders it a necessity, rather than a superfluous luxury.

A strict dichotomy between luxury and necessity, therefore, is a false one. This is because such understandings are relative, rather than absolute. A sense of luxury worth is not intrinsic within an object. What deems an item a luxury is predicated by how much someone is willing to give up to acquire it, and this may well differ from person to person, or social group to social group, and in consideration of the contexts in which such luxuries will be used to communicate their message of value. As the anthropologist David Graeber observed, any notion of such prestige can exist only within a web of social relations (Graeber 2001, p. 9). Value, therefore, is the way people represent the importance of their own actions to themselves, reflected in a socially recognised form; it is not the forms themselves that are the source of value, however (Graeber 2001, p. 47).

Furthermore, our perspectives of value rely upon variability and inequality. Luxuries are expressions of wealth and status values, and concurrently barriers to such levels of wealth and status. Luxuries have therefore often been the subject of discourse from earliest historical times. Greek and Roman authors discussed the impact of luxuries upon social behaviours, in some periods positively and at other times negatively. Specifically, ancient authors speak about luxuries in contexts that distinguish the luxury users from other classes or other cultures. They make distinctions between obtaining wealth and a lifestyle of luxury, which goes hand in hand with an attitude of material entitlement that is met by the physical paraphernalia of luxury. This is the concept of $\tau \rho v \varphi$, which is often translated as luxury, or softness or daintiness associated with luxury. Aristotle explicitly notes in his Nicomachean Ethics that $\tau \rho \cup \varphi \eta$ as luxury is a kind of moral softness (1150b), while Athenaeus' description of the fate of the Campanians during their war with Hannibal (12.528b) makes it 
clear that luxury and extravagance derived from their fertile land led to their downfall, as just two examples (see also Gorman and Gorman 2014; Parker 2002). In short, the sense of worth of a luxury remains tied to social and economic structures within a society (e.g. Appardurai 1986; Gell 1998; Gosden 2005; Graeber 2001; Kopytoff 1986; Papadopoulos and Urton 2012; Porter 2012; Renfrew 2012; Walsh 2013).

This brings us directly to the role such exclusive items play in a given socio-cultural context and when they move between them. This lies at the heart of theories surrounding social actors and their role in agency, in which objects, individuals or collectives are capable of producing changes in human behaviours and sociocultural practices. It is well-established that agency cannot be divorced from a particular socio-cultural structure and its habitus, following in the steps of Giddens and Bourdieu (for archaeological perspectives and overviews, see, e.g., Johnson 1989; Dobres and Robb 2000; Pauketat 2001; Dornan 2002; David 2004; Knapp and van Dommelen 2008; Feldman 2014). Common approaches to agency with regard to material culture in the past include a focus on collective agency; individual intentionality; the rational actor; unintended consequences of social struggle; practical rationality within social struggle; as well as non-human and object agency.

For object agency, specifically, the theoretical emphasis lies in how objects shape human behaviour and influence change (e.g. Hodder 2012; Malafouris 2013; Harrison-Buck and Hendon 2018). Specific historical, spatial, social and cultural contexts together play leading roles in understanding this. Object biography also plays a connecting role (Kopytoff 1986; Marshall and Gosden 1999). Less widely recognised in the biography of an object, however, is the role of the chaine opératoire in an object's ability to be a social actor (Joy 2009). More specifically, meaning and significance are built into an object when it is manufactured, and which can be added to and altered during the object's life (Joy 2009, p. 545).

Meaning and significance are also bestowed upon those involved in an object's production by the very act of their making it. This is because luxury objects have a biography of composite participants, and often it is known by all members of the chaine opératoire that the finished product will be an extraordinary one. For example, a gold earring becomes such only after the metal has been mined, melted (to refine), and moulded (on Mesopotamian and Levantine Iron Age jewellery making, see Moorey 1994; Treister 1995). These are tasks not necessarily undertaken by the same individual, yet everyone involved from extraction through distribution would have likely been aware of the intended value of the finished goods. This understanding would likely have influenced their behaviour every step of the way, and perhaps even in terms of social standing within their peer groups. In this way, the act of making means that an extraordinary object in production impacts upon the lives of its makers.

To return to the decorated ostrich eggs, therefore, the aim here is not to assess how the eggs were social actors between connected populations of the ancient Mediterranean (research on this substantial topic is underway by the author). Nor is it to examine the differences between a manufacturer's intended or interpreted function and a consumer's intended or interpreted use (sensu Russell 2004; David 2004). Instead, the present contribution aims to draw out the chaîne opératoire of these extraordinary objects to shed light on the extent to which luxury objects might act upon others beyond their consumers.

\section{Research to date}

As noted above, a recently concluded study sought to determine from where and how ostrich eggs were acquired and worked in the ancient Mediterranean world. The project drew upon the British Museum's collection of ancient Mediterranean ostrich eggshell from the fifth to the first millennia BCE. It combined isotopic analyses with scanning electron microscopy to assess where an egg was laid and distinguish the working techniques used to decorate them. Specifically, strontium, carbon, and oxygen isotope analyses were employed on 40 samples from 11 different sites, almost all of which were in the eastern Mediterranean, to establish whether the eggs had isotope ratios matching the region in which they were found. The study presumed that the Neolithic examples were derived from wild birds, since there is little evidence for long-distance exchange prior to the Bronze Age. In contrast, the Bronze and Iron Age examples may have come from captive or wild birds, since these are eras in which there is evidence for the movement of objects and materials across regions and between groups. Modern eggs from Egypt, Israel, Jordan and Turkey provided comparative data from known latitudes, as well as baseline indicators for farmed birds with a restricted diet. Isotopic indicators have been used to determine the ecologies and climate where an ostrich egg was laid and to distinguish wild from captive birds for the South African species (Johnson et al. 1998), but they had not been applied previously to Mediterranean species, of which there were perhaps two in antiquity (the now-extinct Struthio camelus syriacus in the Arabian peninsula and Levant; and the S. c. camelus across northern Africa, although the genetic difference is ambiguous: Robinson and Matthee 1999; Freitag and Robinson 1993: Fig. 1; Brown et al. 1982, pp. 32-33). Nor had they been considered in conjunction with assessment of decorating techniques. Therefore, isotopic analyses, high-resolution digital microscopy, and scanning electron microscopy (SEM) were employed (for details, see Hodos et al. 2020).

The study made several important discoveries. The team was able to distinguish eggs laid in cooler, wetter environs from eggs laid in hotter, more arid zones in the eastern Mediterranean. Geographically speaking, regions above $30^{\circ} \mathrm{N}$ latitude correspond with a cooler, wetter environmental zone than land south of this latitude; this northerly region includes the Nile delta, as well as the Levant, including Mesopotamia. One of the most surprising discoveries, therefore, was that ancient sites in both environments, and in which ostriches were indigenous, had examples of eggs laid in the other climatic zone. For example, at Amara West (Sudan) and Ur (Iraq), individual examples were found to have significantly different strontium isotope ratios than other eggs excavated at each site, while the carbon and oxygen data revealed outlier examples at Ur (Iraq), A'Ali (Bahrain) and Naukratis (Nile delta). What this indicates is that just because an egg could be sourced locally, not all eggs necessarily came from local contexts. Given the fragmentary nature of the eggs, it is unclear if these were worked or unworked eggs, or not necessarily exclusively one or the other.

In addition, ancient ostrich eggshells examined via the SEM were observed to have fine, intersecting lines unrelated to working and decoration methods, which could be identified separately. Such lines were not visible on modern, farmed eggs examined comparatively. A separate study of ostrich eggshell respiratory pores had previously noted that pronounced ridging and grooving on the eggs of wild birds may be related to the need of eggs laid by wild birds to have stronger shells than the eggs of farmed birds, perhaps to address the effects of environmental stresses (Koyama and Tennyson 2016). In addition, modern wild ostrich eggs have extremely varied oxygen isotope ratios, because the wild birds are non-obligate drinkers, so their body-water is primarily obtained from ingested plants (Johnson et al. 1998). This contrasts with eggs from modern farmed ostriches, who are provided with drinking water; the oxygen ratios of these eggs do map, 
within uncertainty, onto local precipitation values. The oxygen isotope ratios of the ancient eggs in the British Museum study were too high when converted to local precipitation values, which suggests that the birds laying these eggs were not drinking water from a fixed source. Therefore, between the SEM observations and the oxygen isotope data, it seems likely that the ancient eggs studied from the British Museum collection were acquired from the wild, rather than through managed means.

The research team also examined the eggs for working techniques and tool evidence. Working methods identified include polishing, smooth scraping, abrading, pecking, scratching, picking, and shaving. Pigments included red ochre and carbon (reconfirming what had been identified previously by Rathje 1986). The team were able to replicate some of the ancient methods in their experimental modifications to modern ostrich eggshell, including incisions with both $\mathrm{V}$ - and U-shaped profiles, and certain types of scuffing marks, which gives insight into tool types and handling techniques. Some worked features of the ancient specimens could not be replicated, however, and it remains unclear what tools would have been used to produce them. The variety of technical skills used to prepare and decorate the eggs in antiquity was far greater than anticipated, especially when the worked shells were examined via SEM. These results, while inconclusive with regard to shedding light on the precise tools and techniques used to prepare and decorate the eggs, nevertheless reinforce scholarly recognition that ancient craftsmen were extremely skilled.

\section{Contexts for ostrich eggs as social actors}

These results highlight an array of contexts in which these extraordinary objects played roles as social actors. The first is within the producing culture. The analytical methods of the study of the British Museum eggs reveal that they were acquired from the wild in different regions of the eastern Mediterranean and northern Africa, and that egg sources may have fluctuated between relatively local and more distant locations in both the Bronze and Iron Ages. This implies that their trade networks were more flexible, opportunistic and extensive than previously thought (compare with Aruz et al. 2014, pp. xviii-xix).

It remains unclear whether an egg was traded before or after it was decorated, however. Contemporary shipwreck evidencewhich is not especially plentiful to begin with for the Bronze and Iron Ages, relatively speaking-suggests that cargoes could carry raw and finished goods. For example, the Bajo de la Campana wreck of the late seventh/early sixth century BCE, found off the coast of Spain near Cartagena, carried amber, branch wood logs, and globs of resin or pitch as some of the raw goods traded, while finished exotica include boxwood combs, carved ivory dagger handles, elephant tusks, and worked ostrich eggshell (Polzer 2014; Roldán Bernal et al. 1995. The elephant tusks, some of which had Phoenician graffiti, may have been intended as finished objects, given that a number of the inscriptions are votive in nature, or as raw, perhaps recycled, material for ivory carving). On the other hand, the ostrich eggshells found on the Late Bronze Age Uluburun shipwreck, near the southwestern tip of Turkey at Kaş, were blown (emptied) but otherwise unworked (Bass 1997). Therefore, it is possible that some cargoes may have carried just unworked goods, or only worked products, or transported both. It is difficult to assess any such pattern at a fixed time, much less to determine diachronic and regional developments, because the nature of our shipwreck evidence is extremely variable. There are very few shipwrecks of Late Bronze Age date, and none between ca. 1200 and ca. $750 \mathrm{BCE}$, the period when movement between the eastern and western Mediterranean becomes more regularised; by the seventh and sixth centuries BCE, diverse maritime networks were operating around the Mediterranean, and involved cabotage and long-distance routes and maritime vessels (see Hodos 2020, pp. 116-122). The variable nature of our maritime evidence from the late second millennium to the middle of the first millennium BCE renders it difficult to determine the extent to which the first millennium BCE evidence may represent continuity of earlier practices.

The study also highlights the range of people involved in the full chaine opératoire of luxury production. It starts with those who had to track the animals to their nest sites and take their eggs, whether by stealth or killing the parents. Either way, acquiring eggs entailed risk to the tracker. Firstly, it could take days to find nest sites, since a male ostrich's territory may extend up to $20 \mathrm{~km}^{2}$, and nest locations seem to have no relation to nest sites from previous seasons within a territory (on nests and nesting habits, see Bertram 1992, which examines the South African species; the North African and Levantine indigenous ostrich species are now extinct, but given the general similarity of practices between other closely related animal species, it seems relatively safe to presume that their practices would not have been dramatically different to those of their extant sub-Saharan relatives). In addition, the ostrich was recognised as a dangerous animal, especially by the Assyrians, who used it iconographically partly to highlight the might of the king (Collon 1998; Albenda 2005, pp. 97-101). Furthermore, not only is it known that an ostrich can kill a human with a single kick, but other predators equally dangerous to humans inhabited the same ancient landscapes as ostriches, such as lions and elephants (e.g. Collon 1977; Albenda 2008; Karlsson 2016, pp. 133-140). Therefore, even if the tracker chose to kill an ostrich to acquire its eggs rather than merely steal the eggs, the bird itself was not the only threat. What kind of social impact did tracking and acquisition skills bestow upon the tracker (and anyone else involved in collecting eggs, for we do not know for certain that the tracker was the same individual to collect the eggs)?

There are also questions of exchanging eggs, even in areas where ostrich eggs could already be procured. Did eggs from different areas have different perceived values? Who conducted these exchanges? What arguments would an individual have used to persuade someone to acquire their 'foreign' eggs when eggs could be acquired more regionally?

Furthermore, the team learned from ethnographic evidence that ostrich eggs need to dry naturally for 6-24 months after blowing before the shells are ready to be worked; they cannot be put in the sun or an oven to dry to speed up the process (2 May 2017 interview by the author with J. Cutts, President of the former Egg Crafters Guild of Great Britain). This adds to the complexity of the question about trade of the eggs themselves, because we must now consider additional individuals responsible for their storage, and the impact the responsibility of secure, stable storage had upon those in charge of their care during this period. This may have also added to the eggs' luxury status, since it represents a long-term investment before a return can be realised.

Either way, only once the eggs were suitably dried could highly skilled craftsmen proceed to undertake their decoration. Who determined the imagery depicted on the eggs? Were these solely at the discretion of the craftsman or did the patron have a say? How did such decisions impact upon an artisan's own practices and behaviours in life? Traders were then required to transport the eggs from workshops and arrange for their distribution around the Mediterranean by sea and land; luxury goods required a type of secure storage on board to ensure they did not get damaged, misplaced, or stolen, influencing the behaviour of the loaders and perhaps crew members. All of this activity had to take place before an elite recipient could purchase or receive such an object. In short, individuals involved in the production and distribution of this luxury were varied in terms of time, place, 
occupation, and social status. Nevertheless, their engagement in the biography of these objects impacted upon their behaviour and perhaps social status, although the extent to which we can discuss this beyond speculating how, exactly, is limited, given that we have no direct evidence from the individuals themselves. Even so, we now have a better idea of how the luxury industry affected members of a wide range of society and in diverse locales considerably beyond their elite customers, much like it does today, despite our relative neglect in considering this aspect of luxuries serving as social actors.

These eggs also served as social actors between cultures, as more widely recognised already (see above). They are found in many different ancient Mediterranean cultures, who had distinctive material cultures, beliefs, practices, rituals, languages and customs, and who were often in conflict with one another. Nevertheless, these groups shared a common expression of what it meant to be 'elite.' The fact that these eggs are found consistently in elite contexts during the Bronze and Iron Ages around the wider ancient Mediterranean world, including in regions where ostriches were not indigenous, suggests that they played a role specifically as agents of shared status expression alongside their own socio-cultural specificities (e.g. Hodos 2009, 2020). That they remained popular, albeit in exclusive contexts, over the third, second and first millennia BCE demonstrates that they influenced elites in their self-expressions of what it meant to be rich diachronically.

By the second half of the first millennium BCE, however, ostrich eggs are found predominantly only in the western Mediterranean, primarily in regions associated with the PhoenicianPunic realm of southern Iberia, the Balearic islands and the north-west African coast, and their local networks within those landscapes. Their working does not appear to rely on such highly skilled artisans (motifs are mostly painted, and increasingly less elaborately: Savio 2004), and their find contexts are less exclusive, although still recognised as of comparatively elevated status. This hints at how the eggs themselves worked as social actors upon society more broadly diachronically, and how their status evolved over time, as well (further research on this dimension is ongoing by the author in collaboration with C. López-Ruiz).

Thus, these objects are extraordinary for reasons beyond their predominantly luxury status, challenging acquisition, and craftsmanship display. In addition to communicating common understanding while fostering localised differences between cultures and their individual users-in the more traditional understanding of objects as social agents-it is now clear that many more individuals were involved in the making of these objects than previously considered (if considered at all). A complex chain of interpersonal, collaborative relationships existed that necessitated social interaction, knowledge and understanding. The eggs thus had potential to impact upon individual, and group, behaviour and practice at every step of the chaine opératoire. Arguably, there is still much we do not know about the extent to which these extraordinary objects were social actors upon and between those involved in their production and distribution. The extent of our understanding may also remain limited in the absence of emic records of those involved. Nevertheless, consideration of the entire production process draws out the complex and evolving impacts of the luxury material culture industry upon a number of social groups and individuals beyond wealthy consumers, and highlights more substantially the role luxuries play as social actors.

\section{Data availability}

The data that support the findings of this study are available from Cambridge University Press (https://doi.org/10.15184/aqy.2020.14) but restrictions apply to the availability of these data, which were used under license for the current study, and so are not publicly available. Data are however available from the corresponding author upon reasonable request and with permission from Cambridge University Press.

Received: 14 May 2020; Accepted: 29 June 2020;

Published online: 03 August 2020

\section{References}

Albenda P (2005) Ornamental wall painting in the art of the Assyrian empire. Brill, Leiden

Albenda P (2008) Assyrian royal hunts: antlered and horned animals from distant lands. Bull Am Schools Oriental Res 349:61-78

Appardurai A (1986) Introduction: commodities and the politics of value. In: Appadurai A (ed) The social life of things. Commodities in cultural perspective. Cambridge University Press, Cambridge, pp. 3-63

Aruz J, Graff S, Rakic Y (eds) (2014) Assyria to Iberia at the dawn of the classical age. Metropolitan Museum of Art, New York

Barnett RD (1982) Ancient ivories in the Middle East. Hebrew University of Jerusalem, Jerusalem

Bass G (1997) Prolegomena to a study of marine traffic in raw materials to the Aegean during fourteenth and thirteenth centuries BC. In: Laffineur R, Betancourt PP (eds) TEXNH. Université de Liège, Histoire de l'art archéologie de la Grèce antique, Liège, pp. 153-176

Bertram BCR (1992) The ostrich communal nesting system. Princeton University Press, Princeton

Brown LH, Urban EK, Newman K (1982) The birds of Africa, vol. 1. Academic Press, London

Brysbaert A (2013) 'The chicken or the egg?' Interregional contacts viewed through a technological lens at Late Bronze Age Tiryns, Greece. Oxford J Archaeol 32.3:233-256

Collon D (1977) Ivory. Iraq 39:219-22

Collon D (1998) First catch your ostrich. Iran Antiqua 33:25-42

Conkey MW, Hastorf CA (eds) (1993) The uses of style in archaeology. Cambridge University Press, Cambridge

David B (2004) Intentionality, agency and an archaeology of choice. Cambridge Archaeol J 14:67-71

Dobres MA, Robb JE (2000) Agency in archaeology: paradigm or platitude? In: Robb J, Dobres MA (eds) Agency in archaeology. Routledge, London, pp. 3-18

Dornan JL (2002) Agency and archaeology: past, present and future directions. J Archaeol Method Theory 9(4):303-329

Evely D (1993) Minoan crafts. Aström, Göteborg

Feldman MH (2014) Communities of style. Chicago University Press, Chicago

Freitag S, Robinson TJ (1993) Phylogeographic patterns in mitochondrial DNA of the ostrich (Struthio camelus). Auk 110.3:614-622

Gell A (1998) Art and agency. An anthropological theory. Oxford University Press, Oxford

Gorman RA, Gorman V (2014) Corrupting luxury in ancient Greek literature. University of Michigan Press, Ann Arbor

Gosden C (2005) What do objects want? J Archaeol Method Theory 12(3):193-211 Graeber D (2001) Toward an anthropological theory of value. Palgrave, Basingstoke Gunter A (2009) Greek art and the Orient. Cambridge University Press, Cambridge Harrison-Buck E, Hendon JA (eds) (2018) An introduction to relational personhood and other-than-human agency in archaeology. In: Relational identities and other-than-human agency in archaeology. University Press of Colorado, Louisville, pp. 3-28

Haynes S (1977) The Isis-Tomb, do its contents form a consistent group?. In: Neppi Modona A (ed) La civiltà arcaica di Vulci e la sua espansione. Atti del X Convegno di Studi Etruschi e Italici. L.S. Olschki, Florence, pp. 17-29

Haynes S (2000) Etruscan civilization. British Museum Press, London

Hermann G (2000) Ivory carving of the first millennium: workshops, traditions and diffusion. In: Uehlinger C (ed) Images as media. University Press, Fribourg, pp. 267-287

Hicks D (2010) The material-culture turn: event and effect. In: Hicks D, Beaudry M (eds) The Oxford handbook of material culture studies. Oxford University Press, Oxford, pp. 25-98

Hodder I (2012) Entangled. Wiley-Blackwell, Malden

Hodos T (2009) Colonial engagements in the global Mediterranean iron age. Cam Archaeol J 19.2:221-41

Hodos T (2018) Luxuries during the Mediterranean's Iron Age period. In: Fletcher A (ed) An age of luxury: the Assyrians to Alexander. Hong Kong Museum of History, Hong Kong, pp. 10-23

Hodos T (2020) The archaeology of the Mediterranean Iron Age. Cambridge University Press, Cambridge 
Hodos T, Cartwright C, Montgomery J, Nowell G, Crowder K, Fletcher A, Gönster $\mathrm{Y}$ (2020) Origins of decorated ostrich eggs in the ancient Mediterranean and Middle East. Antiquity 94(374):1-20. https://doi.org/10.15184/aqy.2020.14 Ingold T (2007) Materials against materiality. Archaeol Dialogues 14(1):1-16

Johnson BJ, Fogel ML, Miller GH (1998) Stable isotopes in modern ostrich eggshell: a calibration for paleoenvironmental applications in semi-arid regions of southern Africa. Geochim Cosmochim Acta 62(14):2451-2461

Johnson MA (1989) Conceptions of agency in archaeological interpretation. J Anthropol Archaeol 8:189-211

Joy J (2009) Reinvigorating object biography: reproducing the drama of object lives. World Archaeol 41(1):540-556

Kandel AW (2004) Modification of ostrich eggs by carnivores and its bearing on the interpretation of archaeological and paleontological finds. J Archaeol Sci 31:377-391

Karlsson M (2016) Relations of power in early Neo-Assyrian state ideology. De Gruyter, Berlin

Knapp AB, van Dommelen P (2008) Past practices: rethinking individuals and agents in archaeology. Cambridge Archaeol J 18(1):15-34

Koehl RB (2006) Aegean Bronze Age rhyta. INSTAP Academic Press, Philadelphia

Koyama T, Tennyson AJD (2016) Respiratory pores on ostrich Struthio camelus (Aves: Struthionidae) eggshells. Adv Exp Med Biol 923:51-55

Kopytoff I (1986) The cultural biography of things: commoditization as process. In: Appadurai A (ed) The social life of things. Commodities in cultural perspective. Cambridge University Press, Cambridge, pp. 64-91

Le Meaux H (2013) Des ivoires et des oeufs. Mélanges Casa Velázquez 43 (1):85-110

Malafouris L (2013) How things shape the mind. MIT Press, Cambridge

Markoe GE (1992) In pursuit of metal: Phoenicians and Greeks in Italy. In: Kopcke G, Tokumaru I (eds) Greece between East and West, 10th-8th centuries BC. Verlag Philipp von Zabern, Mainz, pp. 61-84

Marshall Y, Gosden C (eds) (1999) The cultural biography of objects. World Archaeol 31(2):169-320

Middleton AP (2009) Beads beyond number: faience from the 'Isis Tomb' at Vulci, Italy. In: Shortland AJ, Freestone IC, Rehren T (eds) From mine to microscope: advances in the study of ancient technology. Oxbow Books, Oxford, pp. 69-78

Moorey PS (1994) Ancient Mesopotamian materials and industries: the archaeological evidence. Winona Lake, Eisenbrauns

Napolitano F (2007) Considerations on the making and use of colours in Etruria during the Middle Orientalising period. Etruscan Stud 10:11-25

Onnis F (2013) The influence of the physical medium on the decoration of a work of art: a case study of the 'Phoenician' bowls. In: Brown BA, Feldman M (eds) Critical approaches to ancient Near Eastern art. De Gruyter, Boston, pp. $159-184$

Parker G (2002) Ex Oriente Luxuria: Indian commodities and Roman experience. J Econ Soc Hist Orient 45(1):40-95

Papadopoulos J, Urton G (2012) Introduction: the construction of value in the ancient world. In: Papadopoulos J, Urton G (eds) The construction of value in the ancient world. Cotsen Institute of Archaeology Press, Los Angeles, pp. $1-50$

Pauketat TR (2001) Practice and history in archaeology: an emerging paradigm. Anthropol Theory 1(1):73-98

Phillips J (2000) Ostrich eggshells. In: Nicholson PT, Shaw I (eds) Ancient Egyptian materials and technology. Cambridge University Press, Cambridge, pp. $332-333$

Poplin F (1995) Sur le polissage des oeufs d'autruche en archéologie. In: Buitenhuis H, Uerpmann H-P (eds) Archaeozoology of the Near East, vol. 2. Backhuys, Leiden, pp. 126-139

Polzer M (2014) The Bajo de la Campana shipwreck and colonial trade in Phoenician Spain. In: Aruz J, Graff SB, Rakic Y (eds) Assyria to Iberia at the dawn of the classical age. Metropolitan Museum of Art, New York, pp. 230-242. 369-370

Porter J (2012) The value of aesthetic value. In: Papadopoulos J, Urton G (eds) The construction of value in the ancient world. Cotsen Institute of Archaeology Press, Los Angeles, pp. 336-353

Rathje A (1986) Five ostrich eggs from Vulci. In: Swaddling J (ed) Italian Iron Age artefacts in the British Museum. British Museum Press, London, pp. 397-404
Renfrew C (2012) Systems of value among material things: the nexus of fungibility and measure. In: Papadopoulos J, Urton G (eds) The construction of value in the ancient world. Cotsen Institute of Archaeology Press, Los Angeles, pp. 249-260

Robtinson TJ, Matthee CA (1999) Molecular genetic relationships of the extinct ostrich, Struthio camelus syriacus: consequences for ostrich introductions into Saudi Arabia. Animal Conserv 2(3):165-171

Roldán Bernal B, Martin Camina M, Pérez Bonet MA (1995) El yacimiento submarino del Bajo de la Campana (Cartagena, Murcia): Catálogo y studio de los materiales arqueológicos. Cuadernos de Arqueología Marítima 3:11-62

Russell L (2004) Drinking from the penholder: intentionality and archaeological theory. Cambridge Archaeol J 14:64-67

Savio G (2004) Le uova di struzzo dipinte nella cultura Punica. Real Academia de la Historia, Madrid

Torelli M (1965) Un uovo di struzzo dipinto conservato nel Museo di Tarquinia. Studi Etruschi 33:329-365

Treister M (1995) North Syrian metal workers in Archaic Greek settlements? Oxford J Archaeol 14:415-418

Walsh JStP (2013) Consumerism in the ancient world: imports and identity construction. Routledge, New York

Winter I (1976a) Carved ivory furniture panels from Nimrud: a coherent subgroup of the North Syrian style. Metropolitan Museum J 11:25-54

Winter I (1976b) Phoenician and North Syrian ivory carving in historical context: questions of style and distribution. Iraq 38:1-22

Winter I (1982) Is there a South Syrian style of ivory carving in the early first millennium BC? Iraq 43:101-130

\section{Acknowledgements}

Funding for the study from which the present article derives was provided by the Gerda Henkel Foundation, The British Museum, and the University of Bristol. The author is grateful to A. Fletcher, C. Cartwright, and J. Montgomery for their interpretations of the analyses that underpin the present article, as well as J. Cutts for her insights into egg carving methods. The author is also grateful to the Mandel Scholion Interdisciplinary Research Center in Humanities and Jewish Studies at the Hebrew University of Jerusalem for their kind support of this publication.

\section{Competing interests}

The author declares no competing interests.

\section{Additional information}

Correspondence and requests for materials should be addressed to T.H.

Reprints and permission information is available at http://www.nature.com/reprints

Publisher's note Springer Nature remains neutral with regard to jurisdictional claims in published maps and institutional affiliations.

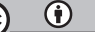

Open Access This article is licensed under a Creative Commons Attribution 4.0 International License, which permits use, sharing, adaptation, distribution and reproduction in any medium or format, as long as you give appropriate credit to the original author(s) and the source, provide a link to the Creative Commons license, and indicate if changes were made. The images or other third party material in this article are included in the article's Creative Commons license, unless indicated otherwise in a credit line to the material. If material is not included in the article's Creative Commons license and your intended use is not permitted by statutory regulation or exceeds the permitted use, you will need to obtain permission directly from the copyright holder. To view a copy of this license, visit http://creativecommons.org/ licenses/by/4.0/.

(C) The Author(s) 2020 